\title{
A note on incentive wages with human capital formation
}

Citation for published version (APA):

Muysken, J., \& Zwick, T. (1996). A note on incentive wages with human capital formation. METEOR, Maastricht University School of Business and Economics. METEOR Research Memorandum No. 022 https://doi.org/10.26481/umamet.1996022

Document status and date:

Published: 01/01/1996

DOI:

10.26481/umamet.1996022

Document Version:

Publisher's PDF, also known as Version of record

\section{Please check the document version of this publication:}

- A submitted manuscript is the version of the article upon submission and before peer-review. There can be important differences between the submitted version and the official published version of record.

People interested in the research are advised to contact the author for the final version of the publication, or visit the DOI to the publisher's website.

- The final author version and the galley proof are versions of the publication after peer review.

- The final published version features the final layout of the paper including the volume, issue and page numbers.

Link to publication

\footnotetext{
General rights rights.

- You may freely distribute the URL identifying the publication in the public portal. please follow below link for the End User Agreement:

www.umlib.nl/taverne-license

Take down policy

If you believe that this document breaches copyright please contact us at:

repository@maastrichtuniversity.nl

providing details and we will investigate your claim.
}

Copyright and moral rights for the publications made accessible in the public portal are retained by the authors and/or other copyright owners and it is a condition of accessing publications that users recognise and abide by the legal requirements associated with these

- Users may download and print one copy of any publication from the public portal for the purpose of private study or research.

- You may not further distribute the material or use it for any profit-making activity or commercial gain

If the publication is distributed under the terms of Article $25 \mathrm{fa}$ of the Dutch Copyright Act, indicated by the "Taverne" license above, 


\title{
A Note on Incentive Wages with Human Capital Formation
}

\author{
Joan Muysken and Thomas Zwick
}

July 3, 1996

\begin{abstract}
This paper shows that investment in human capital may be another reason for incentive wages in addition to "retain, recruit and motivate". It is shown under which circumstances firms pay wages in excess of the market clearing level in order to induce workers to invest. Investment in human capital is inefficient when workers can determine it due to rent sharing and sunk costs.
\end{abstract}

\section{Introduction}

In this note, we want to show that incentive wage considerations may lead to unemployment, if there is a surplus to be divided stemming from investment in human capital. It is argued that the extraction of investment in human capital is costly for the firm and that firm's production costs may be reduced if it pays a wage in excess of the market clearing level. This provides another rationale for the widely accepted observation of efficiency wages in addition to shirking (Shapiro and Stiglitz (1984)), turnover (Stiglitz (1984) and Salop (1979)), adverse selection (Weiss (1980)) and fair wage models (Akerlof (1982) and Akerlof and Yellen (1988)).

The model is constructed such that in the reference scenario, a social planner can determine investment in human capital, the bonus payment for it and the demand for work in order to maximize the rent generated by investment in human capital. If the workers can determine the investment into human capital themselves, the firm may have to set incentive wages that do not clear the labour market in order to motivate the workers for human capital investments. It is, however, also possible that an employment guarantee of the firm combined with incentive wages makes the firm better off.

The note is structured as follows. In the second section, the structure of the model specifying the profit function of the firm and the surplus function of the workers is given. In the third section, the reference scenario with the social planner setting all parameters, the efficiency wage scenario with the workers determining the investment 
in human capital, and the cooperation scenario with side payments of the firm are calculated. In the fourth section the conclusions are discussed.

\section{The structure of the model}

\subsection{The firm}

The firm maximizes its profits. We assume that the production function of the firm is of Cobb-Douglas type ${ }^{1}$. The revenues of the firm depend on the number of workers and the homogeneous level of new human capital gained by the workers in the last period. The firm pays a "basic" wage $w$ and a bonus $b$ dependent on the level of new human capital. Its profit is:

$$
\pi=A l^{\beta} c^{1-\beta}-(b c+w) l
$$

with $0<\beta<1$.

Here the price of the good produced is normalized to unity and $l$ denotes the number of workers demanded, while $A$ is an efficiency parameter. The variable $c$ denotes specific new human capital per worker and it is assumed that without this specific human capital that is gained in the last period, production is not possible. On the other hand, this special human capital is just usable in the firm and not in other employment relations. ${ }^{2}$ The parameter $b$ is the bonus paid for the specific new human capital needed in the firm and $w$ is the "basic wage" per worker that is not related to the level of human capital, i.e. for unschooled labour.

\subsection{The workers}

The workers optimize individually their surplus that is defined as the monetary income, taking into account the consequences on labour demand of the firm. We assume that there is a pool of $L$ homogeneous workers for the representative firm. The focus is therefore on the firm-specific labour market and not on the entire demand for labour. It is assumed that only a part of the labour market is suitable for a job at the firm, e.g. workers in the same branch or recently dismissed labourers of the firm. Therefore all statements about "full employment" and underemployment are with respect to the firm-specific pool of workers. If labour demand is smaller than the pool of workers, then every worker faces by assumption the same chance to lose her job, i.e. the firm does not distinguish between workers and fires at random. For the workers there is a trade-off between the investment in human capital and the certainty to be able to

\footnotetext{
${ }^{1}$ The production function with homogeneous labour input and human capital input is similar to the formulation in Lindbeck and Snower (1991), p. 194. The effort part is substituted by new human capital. Hereby it is implicitly assumed that higher specific job skills lead to higher productivity (such as higher effort leads to higher productivity).

${ }^{2}$ This is actually the definition of "special human capital", see Becker (1983) pp. $26 \mathrm{ff}$.
} 
keep the job, because the labour demand of the firm is falling when human capital (and therefore productivity) is smaller. ${ }^{3}$ The employees are therefore not interested in total labour demand, but in relative labour demand with respect to labour supply $L$.

The surplus function of a representative worker is specified $\operatorname{as}^{4}$ :

$$
s=\frac{l}{L}(b c+w)+\frac{L-l}{L} \bar{s}-(1+r) c^{2}
$$

Here, the workers earn the wage in the primary labour market plus the bonus with chance $\frac{l}{L}$, while they have to subtract the investment in specific capital for sure. Investment costs are quadratic in human capital. The outside option $\bar{s}$ is obtained with chance $\frac{L-l}{L}$. The outside option may be equal to the basic wage rate $w$, if the workers are able to find a job elsewhere where they just get paid the wage of unschooled workers, because they can't use their specific human capital. The outside option may even be lower, if the workers become unemployed. It may be argued, however, that the outside option may be even higher than the basic wage, if the workers are risk-averse and the firm has to offer a risk-premium in order to get workers to investment at all. But it is not necessary to specify the level of the outside option in relation to the basic wage. Therefore we just say, that $\bar{s} \sim w$.

The investment in specific human capital is assumed to show decreasing returns to scale, or the costs of investment are increasing more than proportionally. As the investment is done in the previous period, the costs for specific human capital have to be multiplied by $(1+r)$, where $r$ is the exogeneous rate of interest (or in equilibrium the discount rate of the workers).

If $l \geq L$, the surplus function of the workers reads as:

$$
s=(b c+w)-(1+r) c^{2}
$$

Here it is certain that the workers will stay employed and earn the wage premium in the primary labour market $w$ plus the bonus $b c$, but have to subtract the costs for specific human capital.

\section{Different scenarios}

\subsection{The reference scenario}

In this benchmark scenario, the social planner can set all parameters in order to maximize the rent generated. One way to calculate this is to assume that this rent is entirely given to the firm and therefore profits are maximized. The optimal profit can

\footnotetext{
${ }^{3}$ This is only valid for the relevant larger values of human capital investment.

${ }^{4}$ This is the formulation for the objective functions of workers (unions) most widely used, compare e.g. Layard, Nickell and Jackman (1991), p. 100, Carlin and Soskice (1990), p. 391 and Carrut and Oswald (1987), p. 433.
} 
be calculated by maximizing $\pi$ with respect to $c$ and $l$. The resulting level of profit is negatively related to the bonus paid. If the firm sets the bonus $b$ equal to zero in order to maximize its profits, the workers are not willing to invest for a job that gives them an expected profit lower than their outside option, however. Therefore the lower bound for $b$ is such that the surplus of the workers is the outside option $\bar{s}$. If the profit function of the firm (2.1) is maximized under the constraint that the workers earn at least their outside option, i.e.

$$
s=\frac{l}{L}(b c+w)+\frac{L-l}{L} \bar{s}-(1+r) c^{2}=\bar{s}
$$

the resulting investment and labour demand are:

$$
\begin{aligned}
& c^{\mathrm{r}}=\frac{(1-\beta) A}{2(1+r) L}\left(\frac{\beta A}{\bar{s}}\right)^{\frac{\beta}{1-\beta}} \\
& l^{\mathrm{r}}=\frac{(1-\beta) A}{2(1+r) L}\left(\frac{\beta A}{\bar{s}}\right)^{\frac{1+\beta}{1-\beta}}
\end{aligned}
$$

Labour demand and investment in human capital react parallel to changes in the parameters. Labour demand increases with the efficiency of investment and decreases with its costs. Notice that the labour demand of the firm declines with the number of workers available. This result is due to the fact that if the likelihood of the worker to be employed declines by a given labour demand, i.e. if the pool of workers increases, then a higher bonus has to be offered in order to compensate for the expected loss of sunk investment costs. Labour demand may be lower or higher than the number of workers in the pool, $L$. However, this scenario is only consistent for $l<L$, i.e. there is job uncertainty for the workers. A critical parameter in this respect is the outside option, $\bar{s}$. The higher the outside option of the worker that has to be offered, the lower is the labour demand of the firm. The critical value of $\bar{s}$ is:

$$
\bar{s}^{*}=\beta A^{\frac{2}{1+\beta}}\left(\frac{(1-\beta)}{2(1+r) L^{2}}\right)^{\frac{1-\beta}{1+\beta}}
$$

Hence the analysis only holds for $\bar{s} \geq \bar{s}^{*}$. The profit level that is obtained with "full employment" (or $\left.\bar{s}<\bar{s}^{*}\right)$ ) is derived below.

If $b$ is chosen such that the surplus of the workers is equal to the outside option, or (3.1) is valid, we obtain:

$$
b^{\mathrm{r}}=\frac{L}{l^{\mathrm{r}}}(1+r) c^{\mathrm{r}}-\frac{w-\bar{s}}{c^{\mathrm{r}}}
$$

Substituting all parameter values obtained into the profit function of the firm gives then the optimal profit level of the firm with uncertainty for the workers: 


$$
\pi_{1}^{\mathrm{r}}=\frac{(1-\beta)^{2} A^{2}}{4(1+r) L}\left(\frac{\beta A}{\bar{s}}\right)^{\frac{2 \beta}{1-\beta}}
$$

It can be shown that the rent extracted from the investment in human capital or the difference between revenues and costs of the investment is maximized by setting $c^{\mathrm{r}}$ and $b^{\mathrm{r}}$. Therefore investment is socially optimal in this scenario. ${ }^{5}$

If $\bar{s}<\bar{s}^{*}$, the firm prefers to employ the entire labour force $L$. In this case the profit function of the firm is maximized under the constraint that all workers are employed and earn at least their outside option (which is derived form the surplus function without uncertainty (2.3)).

The accompanying profit level is:

$$
\pi_{2}^{\mathrm{r}}=(1+\beta)\left(\frac{A^{2} L^{3 \beta-1}(1-\beta)^{1-\beta}}{4(1+r)^{1-\beta}}\right)^{\frac{1}{1+\beta}}-\bar{s} L
$$

It can be shown that $\pi_{1}^{\mathrm{r}}$ is always larger than $\pi_{2}^{\mathrm{r}}$ when $\bar{s}>\bar{s}^{*}$, and equal if $\bar{s}=\bar{s}^{*}$.

The relevant profit function for the firm is summarized in Figure 1, where the typical shapes of $\pi_{1}^{\mathrm{r}}$ and $\pi_{2}^{\mathrm{r}}$ are depicted.

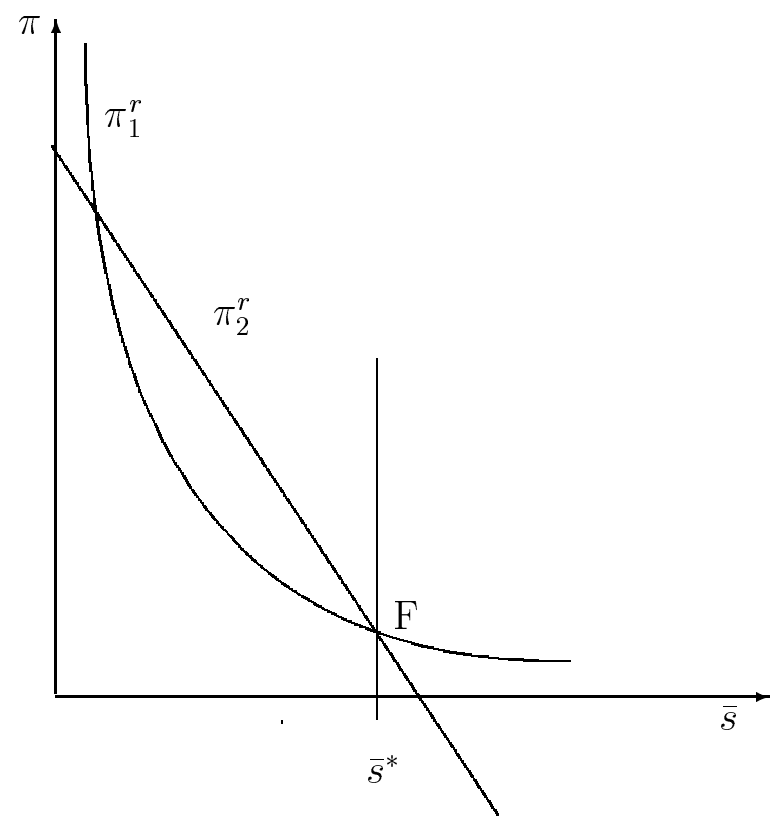

Figure 1: The profit function in the reference scenario.

Since "full employment" occurs for $\bar{s}<\bar{s}^{*}, \pi_{2}^{\mathrm{r}}$ is the relevant part of the profit function to the left of $\mathrm{F}$, whereas $\pi_{1}^{\mathrm{r}}$ is the relevant part to the right. The situation for $\bar{s}>\bar{s}^{*}$ is characterized by underemployment, in the sense that the firm will not employ the

\footnotetext{
${ }^{5}$ Compare Muysken and Zwick (1996), where the social planner maximizes the rent $R$ generated by investment in human capital $\left(R=A l^{\beta} c^{1-\beta}-(1+r) l c^{2}\right)$.
} 
whole relevant labour force. For a given outside option, $\bar{s}$, underemployment will be higher, the lower is $\bar{s}^{*}$. That is, the higher are $L$ and $r$, and the lower $A$. If the number of rivals $L$ increases, job uncertainty increases and bonus demand has to increase in order to match the outside option which reduces the demand for labour $l$. The same applies, if the costs of investment $r$ are rising. If the efficiency of investment decreases however, both $c$ and $l$ are less productive and the demand for labour decreases. We have only discussed the situation in terms of "full employment" (i.e. the employment of the specific labour pool of the firm) and underemployment, and deliberately not in terms of full employment and unemployment. This is due to the fact that $L$ relates to the firm specific labour market.

When we rely on the market mechanism, instead of the social planner, we have to make a difference again between the case where there is less labour demand than supply and that where the entire worker pool is employed. As the investment reaction function of the workers differs slightly in both cases, we construct two scenarios, the incentive wage scenario with job uncertainty and the employment guarantee scenario.

\subsection{The incentive wage scenario}

In the incentive wage scenario, the workers can set their investment in human capital such that their surplus is maximized at a given bonus/employment combination. The firm has to set $b$ and $l$ prior to that decision. This is analogous to other efficiency wage models.

The problem of the firm has to be solved by backward induction. Profit is maximized simultaneously with respect to bonus offer and labour demand taking the reaction function of the workers into account. The human capital supply function of the workers under uncertainty is derived by maximizing the surplus function (2.2) with respect to human capital:

$$
c^{\mathrm{e}}=\frac{l b}{2 L(1+r)}
$$

The higher the bonus offer and the labour demand of the firm, the higher the motivation of the workers to invest in human capital. Due to the sunk-cost property of the investment in special human capital, the investment declines if the chances to stay in the labour market worsen (i.e. $\frac{l}{L}$ decreases). The investment decreases also with the "price" of investment $r$.

If we substitute (3.8) into the profit function of the firm (2.1) and maximize for labour demand and the bonus offer simultaneously, we obtain:

$$
\begin{aligned}
& b^{\mathrm{e}}=2 L(1+r)\left(\frac{w}{A \beta}\right)^{\frac{1}{1-\beta}} \\
& l^{\mathrm{e}}=\frac{(1-\beta) A}{4 L(1+r)}\left(\frac{A \beta}{w}\right)^{\frac{1+\beta}{1-\beta}}
\end{aligned}
$$


The labour demand in the incentive wage scenario is always lower than in the reference scenario with unemployment, given that $w \sim \bar{s}$. The difference increases with the gap between outside option and basic wage and with the importance of human capital for productivity ( $\beta$ increases). In the limit, when human capital has no impact on productivity $(\beta=1)$, both critical values are the same. With incentive wages, the labour demand of the firm is smaller for all values of $\beta$, if $w<\bar{s}$. This constitutes our result that the attribution of the right to set investment in human capital for the workers leads to a reduction in labour demand. This is a consequence of the necessity to pay incentive wages. Notice that the labour demand of the firm is in this scenario smaller than $L$, if $w$ is larger than the following expression:

$$
w^{*}=\beta A^{\frac{2}{1+\beta}}\left(\frac{(1-\beta)}{4(1+r) L^{2}}\right)^{\frac{1-\beta}{1+\beta}}
$$

The smaller the basic wage (or the labour market premium) the cheaper the employment of labour. It is clear that $w^{*}$ is smaller than $\bar{s}^{*}$. This means that underemployment is reached in the incentive wage scenario at a lower exogeneous level of the basic wage than in the reference scenario. The difference between $w^{*}$ and $\bar{s}^{*}$ increases in $\beta$. If the basic wage is very small, it is the best for the firm to employ the entire labour force and we are automatically in the employment guarantee scenario of the next section. Therefore we assume for the remainder of this section that $w>w^{*}$. Notice that if this condition is not fulfilled, the profit of the firm has a kink, because not more than $L$ workers are available. The investment in special human capital in the incentive wage scenario can be calculated now:

$$
c^{\mathrm{e}}=\frac{(1-\beta) A}{4 L(1+r)}\left(\frac{A \beta}{w}\right)^{\frac{\beta}{1-\beta}}
$$

Also the investment in human capital is smaller than in the reference scenario. As the workers do not earn the entire rent generated by investment in human capital, but just the part incentive wages attribute to them, investment is inefficiently small. Notice that due to the investment reaction function of the workers (3.8) the wellknown Solow-condition is fulfilled in the incentive wage scenario, i.e. $\frac{\partial c^{\mathrm{e}}}{\partial b^{\mathrm{e}}} \frac{b^{\mathrm{e}}}{c^{\mathrm{e}}}=1$. The firm minimizes therefore the labour costs per efficiency unit of labour.

Substituting the parameter values (3.10), (3.12) and (3.9) into the profit function of the firm then gives:

$$
\pi^{\mathrm{e}}=\frac{(1-\beta)^{2} A^{2}}{8 L(1+r)}\left(\frac{A \beta}{w}\right)^{\frac{2 \beta}{1-\beta}}
$$

In the incentive wage scenario the profit decreases with the number of workers, because the motivation of the workers to invest in human capital decreases. The profit of the firm obviously decreases with the level of the basic wage $w$. For any reasonable value 
of $\bar{s}$, we find $\pi^{\mathrm{e}}<\pi_{1}^{\mathrm{r}}$ : The profit of the firm decreases of course when the workers are able to set investment in human capital themselves. The difference between $\pi^{\mathrm{e}}$ and $\pi_{1}^{\mathrm{r}}$ decreases in $(\bar{s}-w)$ and $\beta$.

The surplus the workers enjoy is analogously derived by substituting (3.10) - (3.9) into the surplus function of the worker (2.2):

$$
s^{\mathrm{e}}=\frac{(1-\beta)}{4 L^{2}(1+r)}\left(\frac{A \beta^{\beta}}{w^{\beta}}\right)^{\frac{2}{1-\beta}}\left(\frac{1+3 \beta}{4}-\frac{\bar{s} \beta}{w}\right)+\bar{s}
$$

The surplus of the worker is always higher than the outside option, because $\frac{\bar{s}}{w} \sim 1 .^{6}$ Therefore the firm has to share rents with the workers in this scenario.

\subsection{The employment guarantee scenario}

It is advantageous for the firm to offer every worker an employment guarantee, because job uncertainty decreases the motivation of the workers to invest in special human capital. Moreover, profit no longer increases with a lower real wage according to (3.13) once all workers are employed. Having a first-mover advantage, the firm can decide when an employment guarantee and the assorted bonus offer is profit maximizing. In this case, the surplus function (2.3) applies and the investment reaction function of the workers on bonus offer reads as:

$$
c=\frac{b}{2(1+r)}
$$

The bonus offer of the firm is then calculated by optimizing the profit function of the firm (2.1) with respect to $b$, taking (3.15) into account and setting labour exogeneously. equal to $L$. Also in the employment guarantee scenario, the Solow-condition is fulfilled. In this case, the attached profit level of the firm and the surplus level of the worker read as:

$$
\begin{gathered}
\pi^{\mathrm{f}}=(1+\beta)\left(\frac{A^{2} L^{3 \beta-1}(1-\beta)^{1-\beta}}{2^{3-\beta}(1+r)^{1-\beta}}\right)^{\frac{1}{1+\beta}}-w L \\
s^{\mathrm{f}}=w+\left(\frac{(1-\beta)^{2} A^{2}}{16(1+r)^{1-\beta} L^{2-2 \beta}}\right)^{\frac{1}{1+\beta}}
\end{gathered}
$$

The superscript f stands for "full employment". Notice that the surplus level of the workers is higher than the basic wage $w$, i.e. the firm gives part of the rent generated by the investment to the workers. Otherwise the workers would not be motivated to invest. The investment in human capital is again smaller than in the reference scenario with job certainty. As in the incentive wage scenario, the profit of the firm is larger

\footnotetext{
${ }^{6}$ We find $s^{\mathrm{e}}>\bar{s}$ as long as $w>\frac{4 \beta}{1+3 \beta} \bar{s}$.
} 
in the reference scenario with full employment than in the employment guarantee scenario. The difference between $\pi^{\mathrm{f}}$ and $\pi_{2}^{\mathrm{r}}$ decreases again in $(\bar{s}-w)$ and $\beta$.

When comparing both scenarios in the market economy, it can be shown that $\pi^{\mathrm{f}}$ is larger than $\pi^{\mathrm{e}}$ if $w<w^{*}$ and that both profits are equal if $w=w^{*}$. That is, as soon as the wage rate is such that all labour supply will be employed in the incentive wage scenario, it becomes profitable for the firm to guarantee employment. The relevant profit function for the firm then can be depicted, analogous to Figure 1, in Figure 2.

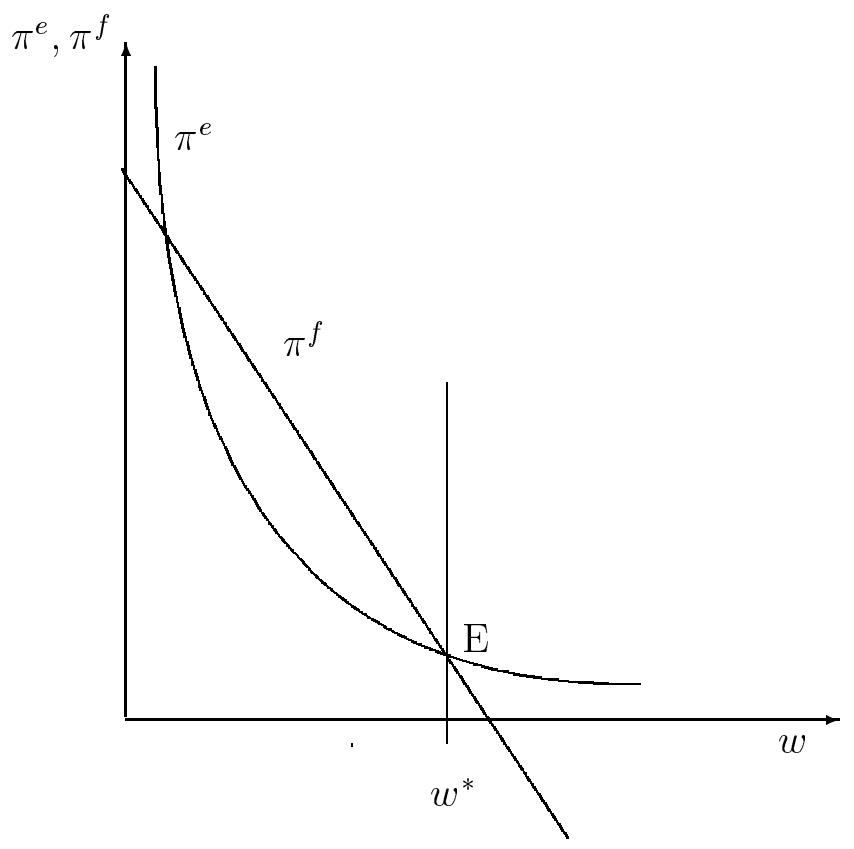

Figure 2: The profit function in the market economy.

In this scenario, "full employment" occurs for $w<w^{*}$. Therefore, $\pi^{\mathrm{f}}$ is the relevant part of the profit function to the left of $\mathrm{E}$, whereas $\pi^{\mathrm{e}}$ is relevant to the right. As in the reference scenario, for a given wage level $w$, underemployment will be higher the lower is $w^{*}$. Comparative statics reveal, that also under market conditions underemployment increases with $L$ and $r$ and decreases with $A$ also under market conditions.

\section{Conclusions}

In this model, it is shown that in a market economy, where workers set their investment in human capital leads to less employment, in comparison to the reference scenario, when a social planner can determine this investment. The model can be summarized in Figure 3 below: 


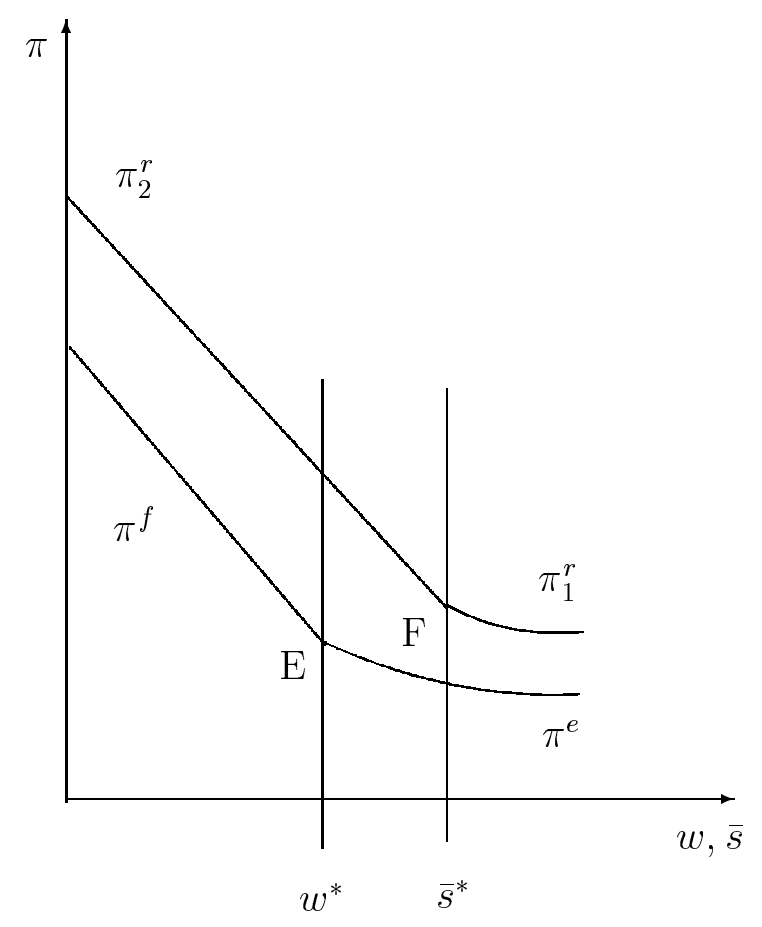

Figure 3: The profit function in the reference scenario and the market economy.

The profit in the reference scenario is dependent on the outside option, while in the other scenarios, it is related to the basic wage. If the impact of human capital on productivity and the gap between outside option and basic wages increases, the critical level of basic wage $w^{*}$ (compare point $\mathrm{E}$ ) that leads to underemployment decreases in comparison to the level in the reference scenario $s^{*}$ (compare point F). In addition, labour demand in the reference scenario is always higher than in the incentive wage scenarios. These results are in line with the efficiency wage theory, where the firm may have to set a higher than market-clearing wage in order to obtain motivated workers in combination with the threat of underemployment. ${ }^{7}$ The notion of stimulating necessary human capital investments in order to increase labour productivity by the payment of an incentive bonus provides therefore a further rationale for efficiency wages in addition to "retain, recruit and motivate". 8

Investment in human capital is inefficiently low when the workers set it in the context of a market economy. This is due to the rent-sharing between workers and firms that attributes part of the rent to the firm. The workers are forced to share rents, because the firm sets the bonus demand in relation to investment and can determine labour demand. In this setting the firm has a motivation to determine the bonus payment higher than the market clearing level if the basic wage is above $w^{*}$, although

\footnotetext{
${ }^{7}$ Compare e.g. Shapiro and Stiglitz (1984).

${ }^{8}$ Compare Layard et al (1991) pp.150 ff.
} 
it would employ all available workers if it could set investment in human capital itself for all values of the outside option smaller than $s^{*}$. The critical wage level is high with high investment efficiency and low with high investment costs and many rival workers. The last phenomenon is due to the fact that investment is sunk and that the motivation of the workers to invest in human capital decreases when the chance to obtain a job at the firm decreases.

We show in this partial equilibrium model which impact the possibility of the workers to determine their investment in human capital has on the labour market performance compared to a social planner solution. The focus is restricted in this case to one firm with a certain pool of workers that require specific skills. All statements are with respect to the employment of this pool of workers. It will be subject to future research to aggregate that model to a general equilibrium model where the unemployment level of the economy can be determined.

\section{References}

[1] George Akerlof: "Labor Contracts as Partial Gift Exchange", in: Quarterly Journal of Economics, 97, pp. 543-569, 1982

[2] George Akerlof and Janet Yellen: "Fairness and Unemployment", in: American Economic Review, 78, pp. 44-49, 1988

[3] Gary S. Becker: "Human Capital", Chicago: The University of Chicago Press, 2nd edition, 1983

[4] Alan Carruth and Andrew Oswald: "On Union Preferences and Labour Market Models: Insiders and Outsiders", in: The Economic Journal, 97, pp. 431 445, 1987

[5] Richard Layard, Stephen Nickell and Richard Jackman: "Unemployment Macroeconomic Performance and the Labour Market", Oxford: Oxford University Press, 1991

[6] Assar Lindbeck and Dennis Snower: "Demand- and Supply-side Policies and Unemployment: Policy Implications of the Insider-Outsider Approach", in : Scandinavian Journal of Economics, 92(2), pp. 279-305, 1990

[7] Assar Lindbeck and Dennis Snower: "Interactions between the Efficiency Wage and Insider-Outsider Theories", in: Economics-Letters, 37, pp. 193-196, 1991

[8] Joan Muysken and Thomas Zwick: "An Insider-Outsider Model with Human Capital Formation", METEOR working paper, 1996

[9] Steven Salop: "A Model of the Natural Rate of Unemployment", in: American Economic Review, 69, pp. 117-125, 1979 
[10] Carl Shapiro and Joseph Stiglitz: "Equilibrium Unemployment as a Worker Discipline Device", in: American Economic Review, 74, pp.433-444, 1984

[11] Joseph Stiglitz: "Alternative Theories of Wage Determination and Unemployment in LDC's: The Labor Turnover Model", in: Quarterly Journal of Economics, 88, pp. 194-227, 1974

[12] Andrew Weiss: "Job Queues and Layoffs in Labor Markets with Flexible Wages", in: Journal of Political Economy, 88, pp. 526-538, 1980 